\title{
Profile of currently employed European food scientists and technologists: Education, experience and skills
}

\author{
Katherine Flynn ${ }^{\mathrm{a}}$, BÁrbara Ruiz Bejarano ${ }^{\mathrm{b}}$, Erik Wahnström $^{\mathrm{c}}$, CAMelia Echim $^{\mathrm{d}}$, \\ AND MAFAlda A.C. Quintas ${ }^{\mathrm{e}}$ \\ a The European Association for Food Safety, 'SAFE consortium', Rue Vanderborght, 20, 1081 Brussels, \\ Belgium \\ b AINIA Centro Tecnológico. Benjamin Franklin, 5-11. 46980 Paterna, Spain \\ ${ }^{c}$ SIK - The Swedish Institute for Food and Biotechnology, Box 5401, SE-402 29 Gothenburg, Sweden \\ ${ }^{\mathrm{d}}$ UGent - The University of Gent, Coupure Links 653, 9000 Gent, Belgium \\ ${ }^{\text {e }}$ CBQF/Escola Superior de Biotecnologia, Rua Dr Antonio Bernardino de Almeida, 4200-072 Porto, Portugal \\ ${ }^{*}$ Corresponding author \\ katherine.flynn@safeconsortium.org \\ TEL: +33669 107177
}

Received: 16 October 2012; Published online: 18 October 2013

\begin{abstract}
The food and drink $(F \& D)$ sector in Europe ranks low in innovation and the European F\&D industry has been losing importance in the global market. The food professionals, i.e., food scientists and technologists (FSTs), may not be meeting the varied demands of the sector. Here, education, experience and skills of current FSTs were identified and compared geographic regions and employment areas. Between 2009 and 2012, 287 questionnaires representing over 4000 FSTs were collected from employers in 16 countries. Analyses showed that more than $80 \%$ of FSTs have a university degree; but only in Industry in the Central European region are most degrees in food science/technology. More than half of FSTs, and almost $60 \%$ in the South, have less than 10 years' experience. The most common FST job title is Quality Manager, but with several variations based on region and employment area. Among skills, the most common is Communicating; found in over $90 \%$ of FSTs in all regions and employment areas. Food Safety is the most common of the food sector-specific skills, present in more than $75 \%$ of FSTs, yet there are differences in food sector skills based on employment area. Overall, these data suggest similarities among currently employed food professionals throughout Europe; they are young and highly educated, but also differences, especially in their food sector-specific skills. An understanding of the current FST should contribute to the improvement of FST training and thus benefit the European food sector.
\end{abstract}

Keywords: Food Scientist; Food Technologist; Education; Training; Skills; Soft Skills

\section{Introduction}

The food and drink (F\&D) sector is one of the most varied in terms of diversity of employment: industry of all sizes and specialities, research institutes, government regulatory agencies and other, non-traditional enterprises, all employ professional food scientists and technologists (FSTs). The F\&D industry, despite being the single largest manufacturing sector in the EU, has been in the lower part of the innovation performance ranking and has been losing relative 
importance in the global food market. One of the reasons for the decline may be technological changes in F\&D employment areas and a lack of corresponding training of FST professionals. Another could be the difficulty in forecasting skill needs for a rapidly changing sector which recently shifted from a product-centred industry to a customer-centred market. In either case, one of the first steps in providing industry and other F\&D employers with the professionals they need is to identify the profile of the current employee. Efforts to identify the current FST have generally been undertaken on a national scale. In the UK, for example, a food manufacturing study divided FST skills into three broad categories (Personal Attributes, Basic and Generic Skills, Vocational Skills) and reported a severe shortage in Personal Attributes but gave no information on worker education or experience (Dench, Hillage, Reilly, \& Kodz, 2000). This study considered less than 50 food industries. A later UK study on skills for agriculture and food looked at high level skills in different employment areas and reported shortages for "niche skills" including plant pathology and flavour science, yet "broader areas of expertise" such as informatics and science communication did not show shortages (Beddington, 2010). These authors pointed out the difficulties arising from the many gaps and lack of consistency within the UK data, they warned that problems could be masked and conclusions confused. An Irish study on food sector employees examined profiles only of those working for Industry; slightly more than half were reported to have no university degree, there was no breakdown of degree type and all FSTs were considered as having a "professional occupation" with no further enumeration of their skills (Expert Group on Future Skills Needs (EGFSN), 2008). These examples attest to the fragmentation of available data about the F\&D sector employee and the difficulties even within a single country of comparing data from different national sources. Additionally, while levels of education and years of experience may be easily comparable, very different skill categories have been used making Europewide comparisons and conclusions even more difficult.

The terms "skill", "knowledge" and "competence" have been individually defined by educa- tional institutions and by the European Commission (European Commission, 2008) but their common use may overlap and a clear distinction is not easy, especially for the non-specialist. Thus, here, for simplicity, the term "skill" is used with the acceptance that it sometimes may be referring more to knowledge or to competency. Recent work on skill requirements for successful employment has pointed to the importance of soft skills; also called personal attributes, character traits or generic, key, transferable or generalizable skills. These are skills such as communication or team work; they are used in a wide variety of contexts and their mastery is associated with success in many fields (Dearing, 1996). Nonetheless, they are often overlooked, especially in more scientific and technical lines of work. In order to clearly differentiate, the questionnaire asked specifically about the soft skills present in FSTs and separately about their food sector-specific skills.

Here, the profile of the current FST in $16 \mathrm{Eu}-$ ropean countries and five employment areas was analysed using a questionnaire directed to FST managers or human resources departments. It was therefore not a self-evaluation, but an employers' view of their employees. The aim was to define the currently employed European FST and to determine if differences exist based on geographic region and/or employment area. To our knowledge, no such study of the European FST exists.

This work is a part of the Track_Fast project, which seeks to increase innovation in the European $\mathrm{F} \& \mathrm{D}$ sector by

1. identification of training and career requirements of future European FSTs, and

2. implementation of a European strategy to recruit the next generation of FST leaders.

The first step in the project, identification and definition of personal skill requirements, includes this profile of the current FST, a definition of the "ideal" FST (Flynn, Wahnström, Popa, RuizBejarano, \& Quintas, 2013), and where and when $\mathrm{s} /$ he should be trained (manuscript in preparation). Other parts of the project include

1. Developments for the regulation of food science and technology professions in Europe; 
2. Establishment of a framework for continual professional training and career development for the FST professional (visit: www.foodcareers.eu); and

3. Motivation of young people to enter and pursue a career in food science and technology in Europe (visit www.foodgalaxy.org).

\section{Materials and Methods}

\subsection{Questionnaires}

The questionnaire was prepared by a team of three food sector professionals: a university professor, an industry association representative and a research consortium representative. It was nine pages with 24 questions and divided into three sections: organization profile, FST academic and career status and competencies and skills desired in FSTs. A data protection notice and informed consent were prepared alongside the questionnaire and a statement guaranteeing confidentiality was included on the first page.

In the organization profile, demographic data were collected including geographical location, number of total and FST employees and employment area (Industry, Government, Research or Other, e.g., distribution or retail). In FST academic and career status, questions concerned the currently employed FSTs at that organization, including highest degree and specialty; years of work experience; skills possessed and employer satisfaction. In competencies and skills desired in FSTs, the questions concerned ideal skills and job titles. Questions were a mixture of choices from a list and open answers and statistical analyses were performed accordingly. The questionnaire was developed in English and then translated into French, German, Greek, Hungarian, Italian, Lithuanian, Portuguese, Romanian, Slovenian, Spanish, Swedish and Turkish by Track_Fast partners in those countries.

Questionnaires were distributed by email in December 2009 to 302 representative FST employers in 15 countries; a list prepared by Track_Fast partners from those countries and aided by an internet-based investigation. In February 2010, questionnaire collection was closed with a total of 109 responses representing at least 2172 FSTs from 15 countries and this data was analysed for an internal Track_Fast report (Ruiz, Flynn, Echim, \& Lindbom, 2010). Following both internal and external expert reviews, the questionnaire was shortened to 10 questions while maintaining the categories described above. The questionnaire was re-distributed to participants at 16 brainstorming workshops on ideal skills organized by Track_Fast in 2010 and 2011 (see Flynn et al., 2013) and further or repeatedly distributed to contacts of the 16 Track_Fast partners. An additional 178 questionnaires were collected. In May 2012, questionnaire collection was closed with a total of 287 responses representing at least 4069 FSTs from 16 countries.

\subsection{Data Organisation and Analysis}

All data were entered into an electronic spread sheet by one researcher and checked for accuracy by another. Comments were translated to English by the local partner. Questionnaires with missing or conflicting information were eliminated from the analysis. Responses to each question were analysed for relationships with

1. geographical region as provided by the Track_Fast partner who distributed the questionnaire and

2. employment area as identified by the response to question 1.

Question 2 on organisation size was used to separate industry responses into two employment areas: $S M E$, defined as fewer than 250 employees and Large Enterprise. The 16 participating countries were grouped into four regions as shown in Table 1.

Questions 7, 8 and 11 concerning university degree and certifications were analysed together such that total employees could be calculated and then percentages with different degrees. For questions concerning skills and job titles (13, 14 and 23), multiple responses were possible and thus totals for each response were divided by total responses using an Excel ${ }^{\circledR}$ pivot table so that the top three choices could be identified 
for each employment area and geographical region. For questions 13 and 14, regarding soft and food-specific skills, three researchers together assigned each choice to a specific skill using the list found in Knowledge and Skills Requirements for Careers in the Food Industry (Ho, Lindbom, \& Wahnström, 2011). These are the same skill classifications recently used for identifying most desired FST skills (Flynn et al., 2013) and they are shown in Table 2. The observed values for skills in the current FST were compared with expected values using a chi square test with $\mathrm{p}$ $<0.05$ required for significance. Expected was defined as the same percentages of FSTs with the same skills in all geographic regions and employment areas.

Table 1: Organisation of 16 participating countries into 4 geographic regions

\begin{tabular}{llll}
\hline Central & East & North & South \\
\hline Austria & Hungary & Belgium & Greece \\
France & Lithuania & Netherlands & Italy \\
Germany & Romania & Sweden & Portugal \\
Slovenia & Turkey & UK & Spain \\
\hline
\end{tabular}

\section{Results and discussion}

\subsection{Questionnaires}

Between December 2009 and May 2012, 287 questionnaires were collected from the 16 partner countries of the Track_Fast project; 6 of these questionnaires could not be used either because of missing or contradictory information. Finally, 281 questionnaires representing approximately 4000 FSTs were analysed. It is necessary to say "approximately", because the number of FSTs was never asked directly. The information came from 3 questions (Q2. How many FSTs are there in your company/organisation (approximate number)?, Q3. How many FSTs in your organisation have a degree? and 4. How many of your staff work as FSTs, but have no degree? combined and Q6. How much work experience do the FSTs in your organisation have? Indicate approx. how many have each of the following years of experience). These three methods of obtaining number of FSTs per respondent did not always give identical results. In Table 3 , the most conservative i.e., the lowest numbers are reported. The distribution of responses by region, employment area and size of the company are presented in Table 3. It can be seen that countries in the East (Hungary, Lithuania, Romania and Turkey) had the highest participation, 99 questionnaires representing over $1100 \mathrm{FST}$, with 72 responses from Industry. In this regard, it is interesting to note that the F\&D industry in these Eastern countries is much less productive, as estimated by the ratio between net sales and number of employees (Food Drink Europe, 2012) than the participating North, Central or Southern European countries. This, together with recent EU membership, perhaps motivated F\&D employers to contribute to the study.

\subsection{Education and Experience}

In each geographical region, more than $80 \%$ of professionals working as FSTs had a university degree (BSc, MSc or PhD) (Fig. 1A). The number of those with degrees specifically in Food Science and Technology was near 50\% in the North, South and East while for Central Europe, this value was lower: $38 \%$. This was unexpectedly low in a region that includes Germany and France, which together represent more than $40 \%$ of food industry net sales in countries considered here (Food Drink Europe, 2012). However, looking only at industry (Large Enterprise and $S M E$ ), one sees that the Central region had the highest percentage of FST degrees, $86 \%$ (Fig. 1B), suggesting that professionals with the knowledge and competences acquired from an FST degree may contribute to the competitiveness of the food industry in this region.

Overall, $S M E$ had a lower number of FSTs with university degrees than Large Enterprises, yet those with degrees in FST were in a higher percentage in SMEs. Perhaps the multidisciplinary nature of this degree (Oliveira \& Medina, 1997) fits the requirement of multiple functions performed by the professionals in an SME. These results may also be influenced by the probable high number of professionals with FST degrees working as consultants (categorized as industry in this study) - many micro and small companies 
Profile of European Food Scientists |141

Table 2: Assignment of questionnaire choice to published list of soft and food sector-specific skills.

\begin{tabular}{lll}
\hline SOFT SKILLS & Questionnaire Choice & Skill from Ho et al. (2011) \\
& Communication, oral & Communicating \\
& Communication, written & \\
& Presentation Skills & \\
& English Language & \\
& Other Languages & \\
& Computer Literacy & \\
& Project Management & Managing Information \& Computer Literacy \\
& Group Worker & Participating in Projects \& Tasks \\
& Group Leader & Working with Others \\
& Financial Skills & Providing Leadership \\
& Statistics/Mathematical Skills & Finance \& Resource Management \\
& Marketing/Consumer Knowledge & Using Numbers \\
& Saboratory \&esearch & Research Marketing \\
\hline FOOD SECTOR- & \\
\hline & Research \& Development & Product Development \\
Packaging & \\
Production & Production Management / Operations \\
& Quality Management & Quality Management, Quality Assurance \\
& \& Quality Control \\
& Engineering & Engineering Maintenance \\
& Food Safety & Food Safety Management, Food Hygiene \\
& \& Food Safety Control \\
& Food Legislation & Food Legislation \& Control \\
Environmental Issues & Health, Safety \& the Environment \\
Logistics & Transportation \\
Consumer Science & Consumer \& Nutritional Sciences \\
Market Trends & \\
\hline
\end{tabular}

Table 3: Distribution of returned questionnaires by region, employment area and size of the organization. Most conservative estimate of number of FSTs represented is indicated in parentheses

\begin{tabular}{|c|c|c|c|c|c|}
\hline \multicolumn{2}{|c|}{ Region } & \multicolumn{2}{|c|}{ Employment Area } & \multicolumn{2}{|c|}{ Size (employees) } \\
\hline Central & $\begin{array}{c}55 \\
(717)\end{array}$ & Large Enterprise & $\begin{array}{c}47 \\
(1332)\end{array}$ & 1 to 25 & $\begin{array}{c}80 \\
(373)\end{array}$ \\
\hline & & SME & $\begin{array}{c}154 \\
(879)\end{array}$ & & \\
\hline East & $\begin{array}{c}99 \\
(1126)\end{array}$ & Government & $\begin{array}{c}21 \\
(449)\end{array}$ & 25 to 100 & $\begin{array}{c}93 \\
(1163)\end{array}$ \\
\hline North & $\begin{array}{c}66 \\
(1329)\end{array}$ & $\begin{array}{c}\text { Research } \\
\text { and Academia }\end{array}$ & $\begin{array}{c}33 \\
(876)\end{array}$ & 100 to 250 & $\begin{array}{c}42 \\
(588)\end{array}$ \\
\hline South & $\begin{array}{c}61 \\
(897)\end{array}$ & $\begin{array}{c}\text { Other (ex. } \\
\text { Retail, Catering) }\end{array}$ & $\begin{array}{c}26 \\
(506)\end{array}$ & $\begin{array}{c}\text { More than } \\
250\end{array}$ & $\begin{array}{c}66 \\
(1945)\end{array}$ \\
\hline
\end{tabular}




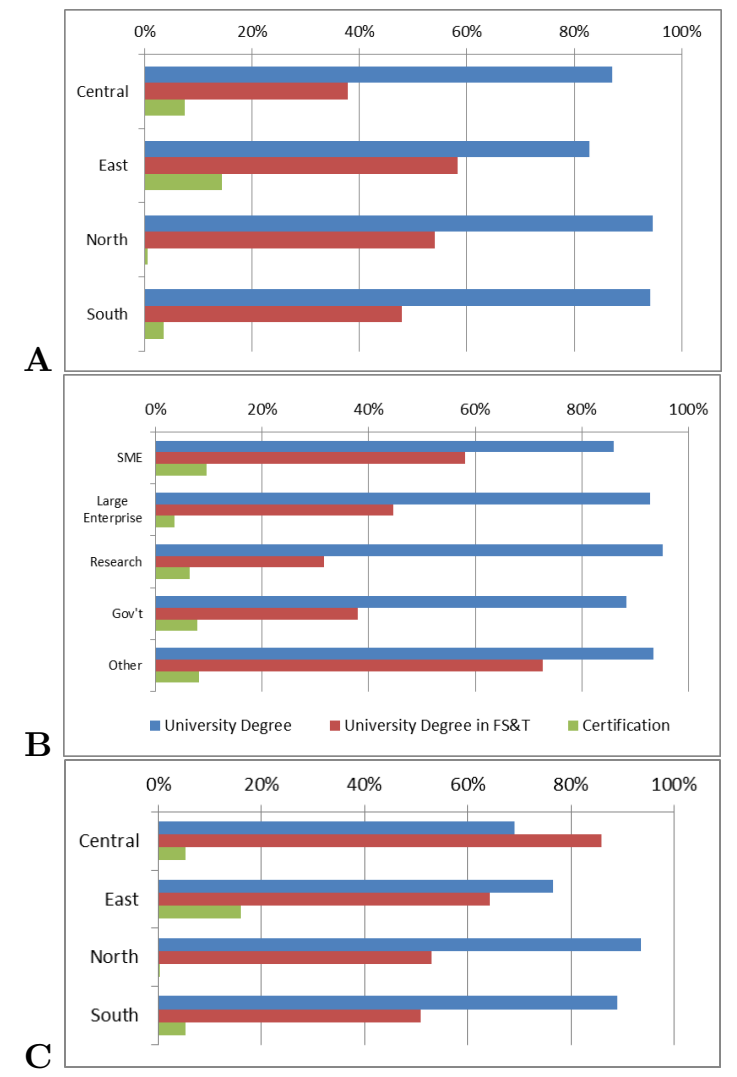

Figure 1: Education of current food scientists / food technologists. Per cent of total FSTs considered (7756) with a university degree (blue bar), per cent of FSTs with a university degree whose degree is in food science or food technology (red bar) and per cent of total FSTs with a certification instead of or in addition to a degree (green bar). A. Per cent in four geographic regions and B. in five employment areas. C. Per cent of total FSTs employed by Industry, SME and Lg Enterprise (3902), with university degree, FST degree and/or certification as above in four geographic regions.

outsource food safety control to small consultancies in their region and this has been a traditional career path for FST graduates. For Other employers (e.g., food distribution and catering), there was also a high percentage with a degree in FST. This may reflect needs in these employment areas regarding food safety - driven by leg- islation, and needs regarding innovation - driven by consumer demand.

Regarding certification, the number of professionals with this was very low, suggesting that either certification in food-related subjects is not valued by employers or that few are available. Certifications were found mostly in the East and were often from a local authority or university, suggesting a region-dependent view. Certifications held by FSTs included those in Quality Management from an independent reference laboratory in Romania, Ecological Production from a certification institute (ICEA) in Italy and "certification courses" from universities in The Netherlands and Lithuania. Certification in Hazard Analysis and Critical Control Point (HACCP) was the only certification mentioned in more than one country; Italy, Slovenia and Turkey. A recent search on a UK site however found 18 jobs for Food Scientists, none of which asked for any food-specific certifications (New Scientist, 2012). The question of certification for food professionals is being addressed by another part of this same European project (Track_Fast) and some conclusions on this topic should soon be available.

Figure 2 shows the distribution of degrees in FST by Bachelor, Master or Doctoral across region and employment. Most FST degrees were Bachelor's in all regions, yet there was also variation. For example, the highest percentage of professionals with a Master Degree in FST was found in the North, perhaps related to the high competiveness and development of industry in this region. Similarly, employers here were the only ones who mentioned Product Development as one of the top three desired FST skills (Flynn et al., 2013), a skill introduced primarily during studies leading to an MSc. As for the distribution of FST degrees by employment area, as expected Research had the highest number of PhDs, followed by Government, SME, Large Enterprise and Other. Within Industry, SME had a higher proportion of professionals with a Master's, while for Large Enterprise a Bachelor diploma seemed sufficient for most positions. This can be a result of a phenomenon of scale: Large industries tend to have larger, concentrated centres for research and development and smaller, more distributed production 
sites - sites where a Bachelor can perform tasks based on procedure manuals which were developed centrally by Masters and Doctorates.

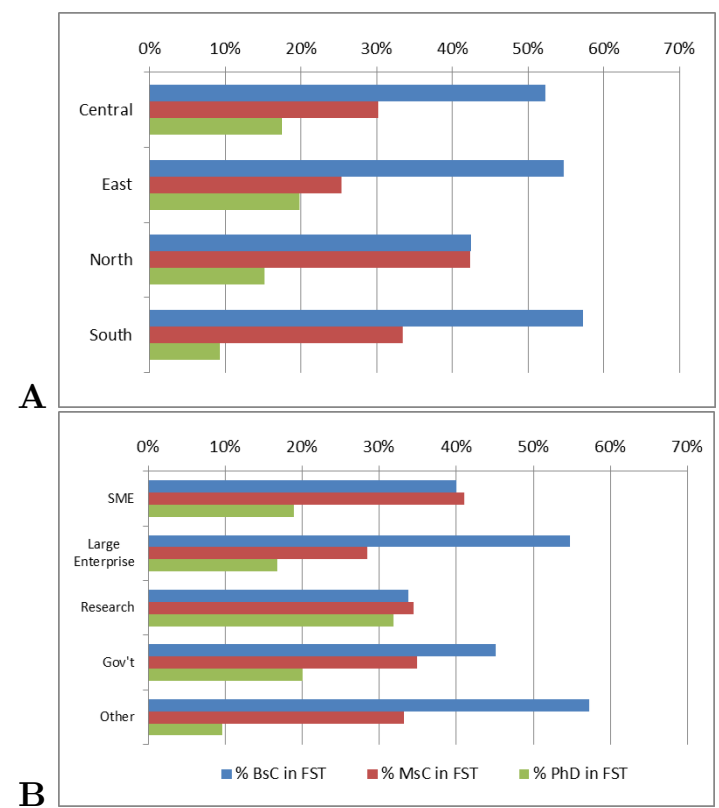

Figure 2: University degrees in Food Science or Food Technology. Per cent of total FSTs with a university degree in Food Science or Food Technology (3231) whose highest degree is a Bachelor (blue bar), a Master (red bar) or a PhD (green bar). A. Per cent in four geographic regions and B. in five employment areas.

The importance of a degree in FST can be evaluated by the satisfaction of employers with the new graduates they hire. To this question, the vast majority, $97 \%$ of respondents, were either "somewhat satisfied" or "very satisfied". Only $3 \%$ (7) were "Not at all satisfied, new employees with practical experience are better than those with diplomas" and these respondents represented only 32 FSTs. These results clearly show that the level of education in Food Science and Technology in European universities is satisfactory and graduates acquire a good understanding of the basic principles needed for success in the F\&D workplace. The need for further training after graduation is only natural: The F\&D sector has very different specificities, e.g. dairy industry is very different from bakery pro- duction and government regulators different from distributors.

It can be seen in Table 4 that the number of working FSTs has not changed much in the last 10 years: $28 \%$ have less than 5 years' work experience, nearly equal to the $27 \%$ with 5 to 10 years' experience. The exceptions were the South region and the employment area Other. The high percentage of new graduates working in the South may reflect job growth, which was the highest among the European regions in this study (Table 5). In Other employment, the high proportion may relate to recent consumer trends: The increase of ready-to-go meals in supermarkets and self-serve restaurants brings a new need for FST professionals in this market. It is also noteworthy that around $50 \%$ of FSTs have more than ten years' experience. This is a relatively low number as this is an interval which continues until the end of working life (circa 40 years). Two factors may influence the relative "youth" of the FST workforce shown here:

1. an increase in the need for FST professionals in the last decade and/or

2. careers of FST professionals tend to progress to more managerial roles,

i.e., no longer considered a Food Scientist or Food Technologist, after 10 or so years into working life.

Table 5: Variation in number of employees in the F\&D industry in the European countries in this study from 2006 to 2010 (calculations based on FDE reports 2008, 2009 and 2011)

\begin{tabular}{lr}
\hline Region & Variation in number of jobs \\
\hline Central & $+6 \%$ \\
East & $-10 \%$ \\
North & $-1 \%$ \\
South & $+11 \%$
\end{tabular}

(Turkey data not available. UK data not considered due to changes in euro-pound conversion rate and UK classification of industry in 2008. Netherlands and Lithuania 2010 data not available - estimated on the average of 2006 to 2009 data.) 
Table 4: Number of years of work experience of food scientists / food technologists in four geographic regions and five employment areas

\begin{tabular}{rrccc}
\hline & & $\begin{array}{c}\mathbf{5} \text { years } \\
\text { or less }\end{array}$ & $\begin{array}{c}\mathbf{6} \text { - 10 } \\
\text { years }\end{array}$ & $\begin{array}{c}\text { More than } \\
\text { 10 years }\end{array}$ \\
\hline & Total (n=4069 FSTs) & $28 \%$ & $27 \%$ & $46 \%$ \\
\hline Region & Central & $34 \%$ & $23 \%$ & $52 \%$ \\
& East & $37 \%$ & $26 \%$ & $47 \%$ \\
& North & $28 \%$ & $28 \%$ & $51 \%$ \\
Employment Area & South & $53 \%$ & $27 \%$ & $39 \%$ \\
\hline & SME & $39 \%$ & $25 \%$ & $47 \%$ \\
& Large Enterprise & $38 \%$ & $28 \%$ & $44 \%$ \\
& Government & $31 \%$ & $20 \%$ & $56 \%$ \\
& Research and Academia & $35 \%$ & $21 \%$ & $53 \%$ \\
& Other (ex. Retail, Catering) & $69 \%$ & $31 \%$ & $28 \%$ \\
\hline
\end{tabular}

Table 6: Job titles of Food Scientists / Food Technologists. Variation in job titles in different employment areas

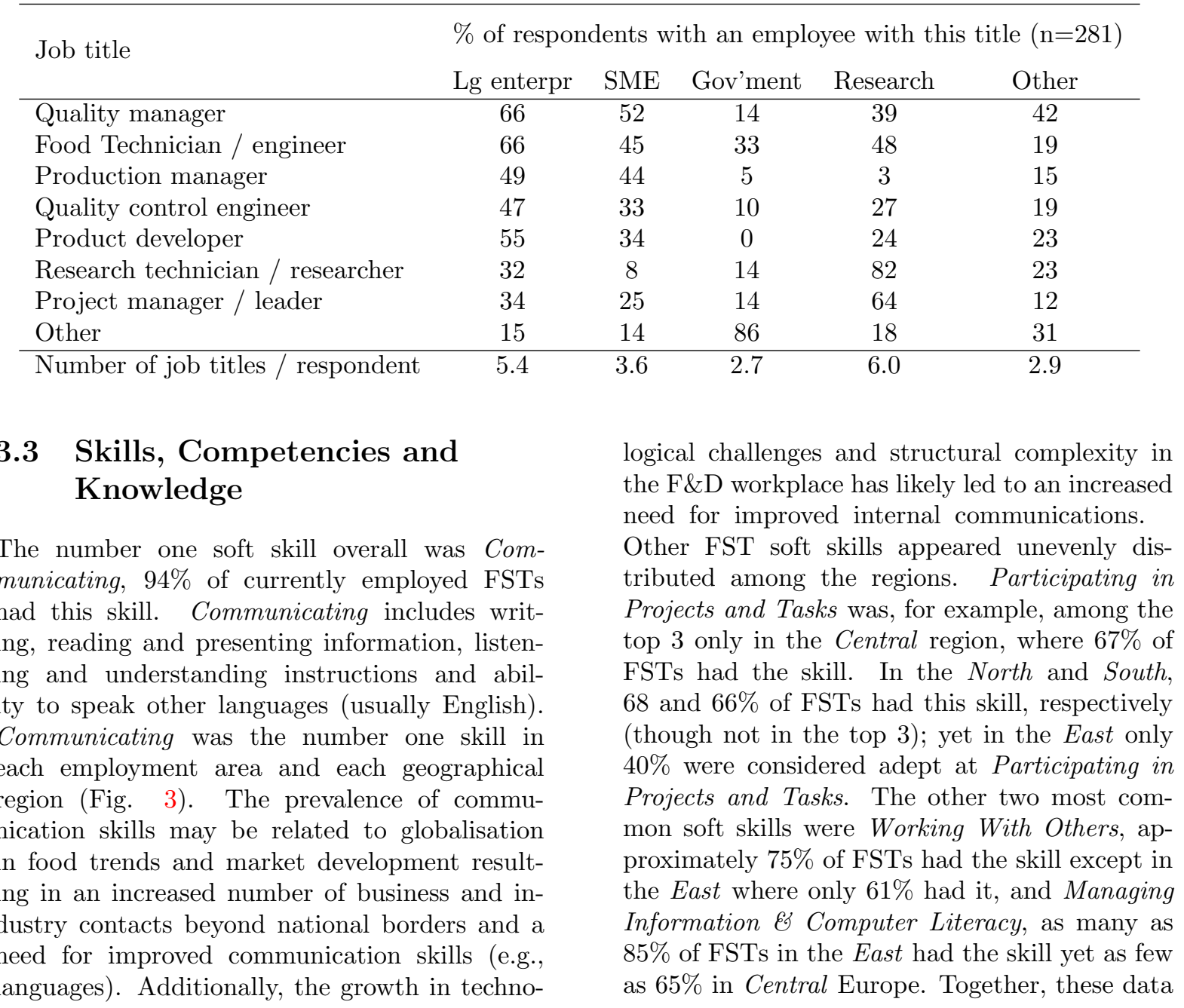




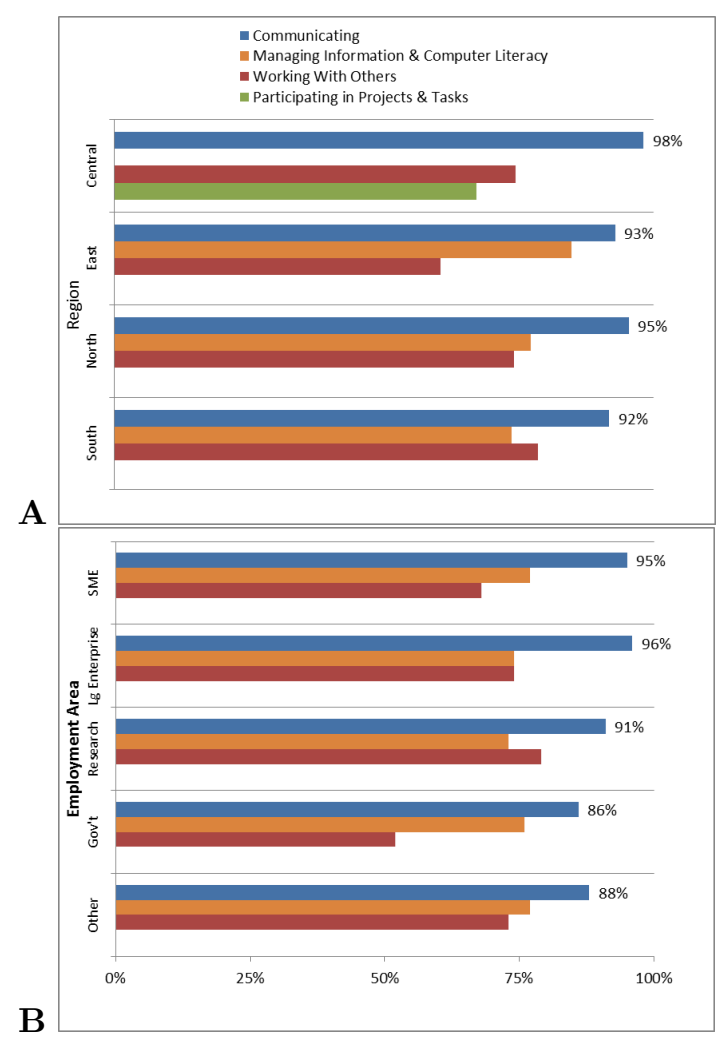

Figure 3: Soft skills in current food scientists and food technologists. Employers (281) indicated which of a list of nine soft skills were found in the "average FST" in their organisation. A. Top three skills in four geographic regions and B. in five employment areas.

suggest a different distribution of soft skills in the FST in the countries of the Eastern region, although statistical significance was not reached. This may be related to newer EU membership for these countries and preceding cultural separation which fostered independent workplace patterns. There were no apparent differences in the distribution of soft skills by employment area: Communicating, Managing Information \& Computer Literacy and Working with Others were the top skills everywhere. This might reflect increasing similarities in F\&D employment areas, both in terms of internal structure and external relations. The growing complexity of knowledgebased work throughout the F\&D sector may also

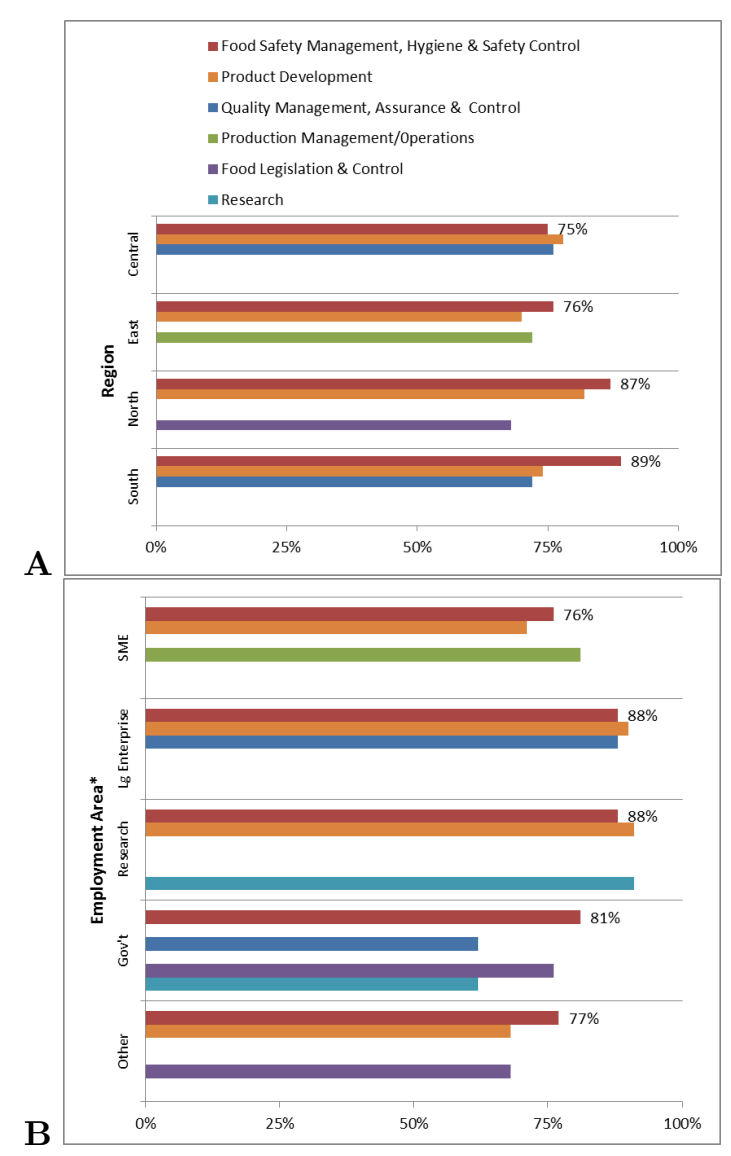

Figure 4: Food sector-specific skills in current food scientists and food technologists. Employers (253) indicated which of a list of 11 food sectorspecific skills were found in the "average FST" in their organization.

contribute to Working with Others and Participating in Projects and Tasks ranking in high positions. It is interesting to note that Communicating is intimately related to and clearly necessary for success in these other high-ranking skills. A recent study on forestry science graduates showed that communication skills are correlated with income, yet not self-evaluated as among the most important soft skills (Rekola, 2012), suggesting that employers and employees may have different views of this skill.

Among the food-specific skills, knowledge and competences, the number one overall was Food Safety Management, Food Hygiene $\&$ Food Safety 
Control, $80 \%$ of FSTs overall and as many as $89 \%$ in the South had this skill. This was the only skill among the top three in all geographical regions and employment areas (Fig. 4). Regionally, Product Development was also among the top three and though food-specific skills appeared to vary by region, the differences did not reach statistical significance. In the East, Production Management $\&$ Operations skills appeared common, $72 \%$ of FSTs, perhaps related to the relative youth of the F\&D industry, reported by Halliday (2009) to be a good investment location for F\&D operations. In the North, $68 \%$ of average FSTs were skilled in Legislation, exemplified by a recent UK job posting for a Food Technologist with knowledge of "labelling legislation" (Greenbank \& Kirk Recruiters, 2012). More research will be necessary to see if these differences are valid.

In the different employment areas, there were statistically significant differences in FST skills $(\mathrm{p}<0.05)$. The only skill in the top 3 for all 5 areas was Food Safety Management, Food Hygiene $\&$ Food Safety Control, clearly demonstrating that safe food is valued by all employers (Fig. 4). For SME, Production Management \& Operations was the number one skill, $81 \%$ of FSTs had it. Since Production skills were also prevalent in the East, it might be that most $S M E$ responses were from the East and/or most East responses were SMEs. In fact there were responses from 62 SMEs in the East (40\% of the total $154 \mathrm{SME}$ responses and $63 \%$ of the 99 East responses) suggesting that being an SME is more closely associated with production skills than with having an East location. SMEs would be expected to focus on Production independent of their location; indeed such a focus was reported to be a necessary part of the success formula for agri-food SMEs in Latin America (RequierDesjardins, Boucher, \& Cerdan, 2003), and in a small operation, this skill would be necessary for the $S M E$. It is also interesting here to compare SMEs to Large Enterprises where many fewer FSTs, only $68 \%$, have Production Management $\&$ Operations skills. This may be explained by the division of labour in Large Enterprises, where most management and operations tasks are likely taken over by employees trained in Business.

Food Legislation 8 Control was among the top
3 food sector-specific skills in Government and Other, where FSTs may be writing and enforcing food-related legislation. As this skill was also more prevalent in the North, perhaps Government and Other samples contained a high number of respondents from the North and/or vice versa. In fact, most Government responses came from Central and East, most Other responses from the South and most Northern responses from Large Enterprise leading us to believe that having an FST with Legislation skills is independently associated both with a Northern location and with a Government or Other employment area.

In the Research employment area, Research was the most common skill, $91 \%$ of FSTs; among Government employers, Research was among the top 3 skills, but only $61 \%$ had this skill. It is perhaps surprising that Research was not among the top in Large Enterprise (56\%), as they are likely leaders in developing new products and packaging and research skills would seem necessary in their FSTs. However this might be due to the phenomenon of scale as hypothesized above for number of PhDs: in a large enterprise there are few central locations which have the highly trained personnel who do the research which is then used by the more numerous distribution centres where the lesser trained professionals are working. Finally, Quality Management, Quality Assurance \& Quality Control was found among the top skills in Government and Large Enterprise but not in SMEs. Here, the day-to-day demands of Food Safety and Production necessary for business survival perhaps favour having FSTs with these skills, moving Quality to a lower priority.

The most common overall job titles in our study were Quality Manager and Food Technician / Food Engineer. These titles were $1^{\text {st }}$ or $2^{\text {nd }}$ in all geographic regions (data not shown) but not in all employment areas. Quality Manager was the most common title in industry (Large Enterprise and $S M E$ ) and Other employers; an FST with this title was found in as many as $66 \%$ of Large Enterprise respondents, but rather uncommon in Government, at $14 \%$ (Table 6). Since 201 of 281 respondents were from industry, this likely contributes to the prevalence of this title overall, but does not explain the variations based on employ- 
ment area. Production Manager was among the top job titles in SMEs, supporting the finding above that Production Management/Operation Skills are the most common food sector-specific skills in SMEs. Although Table 6 suggests more Production Managers in Large Enterprise, it is important to note the higher number of job titles per respondent in Large Enterprise. In Research, a Research Technician / Researcher was found in $82 \%$ of responding organisations, yet this title was uncommon elsewhere. In Government, job title choices were not representative and most respondents had employees with Other titles, examples were Advisor, Secretary and Department Head, indicating that the FST in Government employment has a rather different job than FSTs elsewhere.

\section{Conclusions}

The data presented here outline the profile of the currently employed European Food Scientist / Food Technologist in different geographic regions and different employment areas. While the number of questionnaires analysed (281) is likely not a significant representation of the European F\&D sector, this study did represent several thousand FSTs from varied geographic regions and employment areas and is a starting point for understanding the current status of staff in the F\&D sector across Europe. In short, the average European FST has a university degree, with about half having a degree specifically in Food Science / Food Technology. Those with a degree in FST tend to have a Bachelor's, though in some geographic regions and employment areas a Master's is the norm. The current FST is unlikely to have any food-related Certifications. Most employers are satisfied with graduates in FST, perhaps a result of long-term European initiatives like the ISEKI project, which aim at harmonization of curricula and monitoring the quality of food studies (https://www.iseki-food.net/). FSTs are "young", about half have less than 10 years of work experience.

The same soft skills are found in FSTs working in all geographic regions and all employment areas, with Communicating skills the most common. Our recent report on skills in the "ideal" FST showed Communicating as the most desired skill overall (Flynn et al., 2013), suggesting that at some level FST employers have what they want. Yet when asked to 'design the ideal FST', many more soft skills were mentioned, both variety of skills and number of times, than were food skills. It seems FST training is on the right track in providing the soft skills employers need, but has not yet reached the depth nor breadth of soft skills required. Other reports have come to similar conclusions about the need for soft skills. A recent study by CEFIC (The European Chemical Industry Council) reported that high level industry representatives listed Communication as the number 2 personal skill required for scientists and the number 1 personal skill for engineers (CEDEFOP, 2009). The Canadian Stem Cell Network offered a workshop and published a follow up article on the importance of soft skills for scientists (Rancourt, 2009). More recently, the Australian Association of Engineering Education heard a report on integrating soft skills, including communication, into university engineering courses (Armstrong \& Baillie, 2012).

Food sector-specific skills vary with employment area with three different number one skills in the five areas considered: Product Development, Production and Food Safety. Yet employers want other skills as well, e.g., Food Legislation (Flynn et al., 2013). Additionally, food skills viewed as important by policy makers and perhaps also by the general public, e.g. sustainability and environmental issues on the one hand and nutrition and healthy diet on the other, were not commonly found in current FSTs. While the data here show that FSTs working in different areas of employment have different food-specific skills, the ideal is subtle but important differences depending on both region and employment area for both food and soft skills (ibid.).

These results clearly indicate a need for further attention to skills in the FST workforce. Qualification and training of F\&D professionals is necessary for innovation, yet it has recently been noted that $\mathrm{F} \& \mathrm{D}$ does not make the necessary investment in its workforce (European Technology Platform, Food for Life, 2012). Knowledge of the training needed comes from understanding what employers have and what they want. A regular repetition of this study would provide such 
knowledge and allow understanding of trends in F\&D employee skills. Taken together with other work from the Track_Fast project, these results can contribute to improving the profile of the European food scientist and thus to improving the competitiveness of the food \& drink sector.

\section{Acknowledgements}

The authors thank the coordinator of the Track_Fast project, Prof. Cristina L.M. Silva of the Catholic University of Portugal College of Biotechnology, for support from the inception through the completion of this study. All the Track_Fast partners who translated questionnaires and responses and provided contacts are acknowledged. Finally, all 281 Food \& Drink organisations that took the time to complete a questionnaire are warmly thanked for their effort.

\section{Role of the Funding Source}

This work was funded by the project 'TRACK_FAST: Training Requirements and Careers for Knowledge-based Food Science and Technology in Europe' an SP1-Cooperation, Coordination and Support Action, of the Commission of the European Communities Framework 7 Programme, grant agreement number: KBBE 227220. The funders had no role in the details of the study design, data collection, analysis and interpretation; writing of the report; nor decision to publish.

\section{References}

Armstrong, R., \& Baillie, C. (2012). Engineers engaging with community: negotiating cultural difference on mine sites. Journal of Engineering, Social Justice, and Peace, $1(1), 7-17$.

Beddington, J. (2010). High-level Skills for Food, Report from the Food Research Partnership Skills Sub-Group, Skills Funding Agency UK. Retrieved December 2011 from: http : / / www . bis . gov . uk / assets / bispartners / goscience / docs / h / 10 - 929 high-level-skills-for-food.pdf.
CEDEFOP. (2009). Skills for Europe's future: anticipating occupational skill needs. Panorama series. Publications Office of the European Union, Luxembourg. Retrieved August 2012 from: http://www.cedefop. europa.eu/EN/Files/5194_en.pdf.

Dearing, R. (1996). Review of Qualifications for 16-19 year olds. London: SCCA. Retrieved October 2012 from: www.heacademy.ac.uk.

Dench, S., Hillage, J., Reilly, P., \& Kodz, J. (2000). Producing to Survive. The extent, causes and implications of skill deficiencies in food manufacturing. Skills Task Force Research Paper SKT34, Department for Education and Employment; The Institute for Employment Studies, Brighton, UK. Retrieved October 2012 from: http://www. employment - studies . co . uk / pdflibrary / skt34.pdf.

European Commission. (2008). The European Qualifications Framework for Lifelong Learning (EQF). Belgium: European Commission, Education and Training. Retrieved August 2009 from: http : / / ec. europa.eu / education / policies / educ/ eqf / eqf08_en.pdf.

European Technology Platform, Food for Life. (2012). Strategic Research and Innovation Agenda. Retrieved October 2012 from: http : / / www . fooddrinkeurope . eu / uploads / press-releases_documents / SRIA_ ETP_Food_for_Life_2012.pdf.

Expert Group on Future Skills Needs (EGFSN). (2008). Future Skills Requirements of the Food and Beverage Sector. Dublin. Retrieved October 2012 from: http://www. skillsireland . ie / publication / egfsnSearch . jsp?tp=Sectors.

Flynn, K., Wahnström, E., Popa, M., RuizBejarano, B., \& Quintas, M. (2013). Ideal skills for European food scientists and technologists: Identifying the most desired knowledge, skills and competencies. Innovative Food Science and Emerging Technologies, 18, 246-255.

Food Drink Europe. (2008). Data \& trends of the European Food and Drink Industry 2007. Confederation of the Food and Drink Industries of the EU, Brussels, Belgium. Retrieved July 2012 from: http://www. 
fooddrinkeurope.eu/uploads/publications_ documents/Data_Trends_2007.pdf.

Food Drink Europe. (2009). Data \& trends of the European Food and Drink Industry 2008. Confederation of the Food and Drink Industries of the EU, Brussels, Belgium. Retrieved July 2012 from: http://www. fooddrinkeurope.eu/uploads/publications_ documents/Data_Trends_2008.pdf.

Food Drink Europe. (2011). Data \& trends of the European Food and Drink Industry 2010. Confederation of the Food and Drink Industries of the EU, Brussels, Belgium. Retrieved July 2012 from: http://www. fooddrinkeurope.eu/uploads/publications_ documents/Data_Trends_2010.pdf.

Food Drink Europe. (2012). Data \& trends of the European Food and Drink Industry 2011. Confederation of the Food and Drink Industries of the EU, Brussels, Belgium. Retrieved July 2012 from: http://www. fooddrinkeurope.eu/uploads/publications_ documents/Data_Trends_2011.pdf.

Greenbank \& Kirk Recruiters. (2012). Specification Technologist - Food Manufacturing, Adfinder code: Ref 30492362. Retrieved June 2012 from: http://www.fish4.co.uk/ jobs $/$ advert adId $=30492362 \& w t . m c \_i d=$ aggregator_Indeed.

Halliday, J. (2009). Eastern Europe Offers Growth Momentum, Report. FoodNavigator.com. Retrieved October 2012 from: http://www.foodnavigator.com/FinancialIndustry / Eastern- Europe- offers- growthmomentum-report.

Ho, P., Lindbom, I., \& Wahnström, E. (2011). The Continual Professional Development Portfolio (CPD) for Food Professionals in Europe. Annex B: Knowledge and skills requirements for careers in the food industry. (Report on Deliverable D3.1). Porto, Portugal: Track_Fast: Training Requirements and Careers for Knowledge-based Food Science and Technology in Europe, Grant Agreement No. 227220. Retrieved August 2011 from: https: / / www . trackfast.eu / webfm_send/539.

New Scientist. (2012). Specification Technologist - Food Manufacturing, Adfinder code: Ref 30492362. Retrieved October 2012 from: http : / / jobs . newscientist . com / en - gb / searchjobs $/$ ?Keywords $=$ food + scientist \& Location $=$.

Oliveira, J., \& Medina, A. (1997). The future of food engineering education in Europe. In P. Fito, E. Ortega-Rodriguez, and G.V. Barbosa-Canovas (Eds.). Food Engineering 2000. Chapman and Hall, New York (USA), 403-411.

Rancourt, D. (2009). While Doing Your Science - Monitor Your Soft Skills! PD from the PIs: tips and tricks to enhance your career. Stem Cell Network. Retrieved October 2012 from: http://www.stemcellnetwork. ca/index.php?page $=$ career- development \& $\mathrm{hl}=$ fra.

Rekola, M. (2012). Discipline specific and general skills related to employment and career success. Unpublished paper presented at the ICA - EDU congress, Bolzano, Italy.

Requier-Desjardins, D., Boucher, F., \& Cerdan, C. (2003). Globalization, competitive advantages and the evolution of production systems: rural food processing and localized agri-food systems in latin-american countries. Entrepreneurship \&6 Regional Development, 15, 49-67.

Ruiz, B., Flynn, K., Echim, C., \& Lindbom, I. (2010). The Current State of European FST Competencies. (Report on Deliverable D1.1). Porto, Portugal: Track_Fast: Training Requirements and Careers for Knowledge-based Food Science and Technology in Europe, Grant Agreement No. 227220. Retrieved July 2012 from: https: //www.trackfast.eu. 